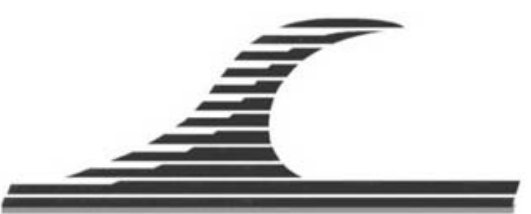

Revue Paralia, Volume 2 (2009) pp 6.1-6.11

Keywords: Built assets, Harbour structures, Experience

feedback, Owners, Inquiry.

\title{
Technical management of French harbour structures Part 1: Description of built assets
}

\author{
Jérôme BOERO ${ }^{1,2}$, Franck SCHOEFS ${ }^{2}$, Bruno CAPRA ${ }^{3}$, Nicolas ROUXEL ${ }^{4}$ \\ ${ }^{1}$ OXAND S.A., \\ 49 avenue Franklin Roosevelt, 77210 Avon, France. \\ jerome.boero@oxand.com \\ ${ }^{2}$ University of Nantes, Research Institute in Civil and Mechanical Engineering (GeM), \\ UMR 6183 CNRS, Faculté des Sciences et des Techniques, \\ 2 rue de la Houssinière, 44000 Nantes, France. \\ franck.schoefs@univ-nantes.fr \\ ${ }^{3}$ OXAND S.A., \\ 49 avenue Franklin Roosevelt, 77210 Avon, France. \\ bruno.capra@oxand.com \\ ${ }^{4}$ CETE de l'Ouest, \\ 5 rue Valles, 22015 Saint-Brieuc, France. \\ Nicolas.Rouxel@equipement.gouv.fr
}

\begin{abstract}
:
This paper focuses on the study of the built assets of French harbour owners with a view to providing elements which can be used in risk analysis.

The structures' functions and position in the system are identified and their relative strategic importance for economic, touristic developments and national defence is highlighted.

The results are presented by focusing the analysis on observed levels of heterogeneity, especially the description of the construction techniques, the materials used and the ages of the built assets.
\end{abstract}

Received 17 November 2008, accepted 20 April 2009, available online 21 December 2009.

The reviewing procedure concerns the version written in English. The version written in any other language is published under the sole responsibility of the author(s).

UNE VERSION TRADUITE EN FRANCAIS EST DIPONIBLE EN LIGNE

How to cite this paper:

BOERO J., SCHOEFS F., CAPRA B., ROUXEL N. (2009). Technical management of French harbour structures - Part 1: Description of built assets. Revue Paralia, $\mathrm{n}^{\circ} 2$, pp 6.1-6.11.

DOI: 10.5150/revue-paralia.2009.006 ～(disponible en ligne - http://www.paralia.fr - available online) 


\section{Introduction}

Maintenance of harbour assets is a major economic and tourist stake. The challenge of the owners consists in guaranteeing the ageing structures operation (wharves, dry docks, dikes, etc.) with good safety, reasonable costs and availability conditions (AIPCN, 2001; AIPCN, 2008). Moreover, the harbour development opportunities are more and more limited in front of increasing environmental constraints and decreasing available space for low cost development.

Currently, the decisions about maintenance are often taken without an overall view of the associated risks. That is why they give place to long and difficult meetings between managers who have various priorities: technical, strategic, financial, etc. Most of the time, maintenance is curative (after unforeseen events) or preventive, with a high cost (anticipation of predictable events) and more rarely, predictive (evolutionary predictions). Decisions are generally based on budgetary, operation and safety constraints. Furthermore, in some cases, structures are operated in more severe service conditions than initially forecasted. In these conditions, owners could face two major risks: uncontrolled maintenance costs or uncontrolled safety and unavailability costs.

To deal with this problem, the GEROM project (Risk Management of maritime and river structures in harbours) was created within the GIS MRGenCi (Grouping of Scientific Interest "Risk management in Civil Engineering") and lies on a partnership between Oxand and the Research Institute in Civil and Mechanical engineering of Nantes. The GEROM project was undergone from 2006 until 2009. It aims to:

a) Collect all the elements necessary for the development of an optimized methodology of technical management.

b) Help owners draw and optimize their decisions concerning the durable management of their structures.

In the first phase, with the support of the CETE de l'Ouest (Ministry of ecology, energy, sustainable development and town and country planning), a national inquiry was carried out with owners about the technical management of the maritime harbour structures.

This national inquiry's preparation was based on the FMECA method (Failure Mode Effects and Criticality Analysis) (VILLEMEUR, 1988; HALDI, 1997) that is more and more developed for hydraulic or coastal infrastructures (SORENSEN \& BURCHARTH, 2004; PEYRAS et al., 2006; BILLARD et al., 2006; BILLARD et al., 2007; BOERO et al., 2006), in particular to define maintenance programs (inspection, common maintenance and repair). Our objective was then to identify and acquire information which can be integrated into a risk analysis applied to harbour structures. Due to the multiple topics addressed during the national investigation, results are presented in two parts. This paper deals with the first part and is focused especially on:

a) The structures' functions (dikes, locks, dry docks, quays, landing stages, bridges, buildings, roads, etc.) and the position of the structures in the system (functional analysis). 
b) The strategic importance for economic and touristic developments, national defence, etc., safety of the installations, security of the persons, environmental protection, control of the direct costs (maintenance) and indirect costs (availability, public image) (consequences, stakes analysis).

c) The construction techniques, ages, materials, geometry, environment (factors affecting the frequency of failure modes).

\section{Progress of the national inquiry on the harbour assets management}

\subsection{Objectives}

The inquiry objectives were to:

a) Facilitate an experience sharing between owners of harbour structures and the various participants of this project.

b) Compile an overview of the existing French national built assets, current maintenance practices (maintenance politics and strategies, experience feedback on the harbours' pathologies, efficiency of technical repair, etc.) and needs in this domain.

\subsection{Spatiotemporal perimeter}

This inquiry was performed from January $24^{\text {th }}$ to May $12^{\text {th }} 2006$, and was completed in the first quarter 2007. The geographical perimeter covers a total amount of 7 Autonomous Harbours (AH), 16 National Interest Harbours (NIH) and 3 Military Harbours (MH) located along the French metropolitan coast. The status of AH have changed since the law of July 4th, 2008 and since its implementing decrees, in particular those of October 9th, 2008.

The 532 harbours, that have been decentralized since 1984, and managed by the General Councils of departments or Municipalities, were not integrated in this study because of their large number. However, some of them were interviewed (without inquiry's support) in order to have an overall view.

Further to the recent decentralization of the NIH since January $1^{\text {st }} 2007$, the status of NIH no longer exists. In this article, this status was preserved to make the distinction with harbours already decentralized in 1984.

The referees are technical managers of harbour structures, and the following sources were used to contact them:

a) The partners of the GEROM project.

b) The maritime structures' club (meeting reports).

c) The AITPE 2005 (directory of the Association of the State Public Works Engineers).

d) The harbours websites. 


\subsection{Inquiry's process}

The inquiry's process comprises several steps starting with researching potential contacts, phoning to confirm contacts and mailing a short questionnaire for an interview of approximately 2 hours.

This process obtained a very good level of return. In fact, of the 23 contacted harbours $(\mathrm{AH}, \mathrm{NIH}, \mathrm{MH}), 19$ returned the filled questionnaire and were interviewed, that represents approximately $85 \%$ of the targeted owners.

\subsection{Themes}

The various selected themes correspond to the different stages of the built assets management cycle:

a) Know: which built assets have to be managed?

b) Organize: what are the available resources and how must they be structured?

c) Estimate: what is the performance of the built assets with regard to their functions and what are the associated risks?

d) Forecast: how to predict the evolution of risks?

e) Evaluate: what are the acceptable risks over the short and long-term?

f) Define: what are the actions to control risks?

g) Plan: which are the actions to do first, considering the maintenance constraints (financial, technical and exploitation)?

h) Capitalize: what information must be capitalized to optimize the management cycle of the built assets?

\section{Role and importance of the French harbour system}

The French harbour system has an essential role: on the one hand for French business, tourism and industry; and on the other hand for European defence.

\subsection{Military harbours}

Along with Great Britain, France is the only State member of the European Union that owns a navy with world vocation: it should be able to be present on all the seas of the world and to deploy nuclear deterrence (MARINE NATIONALE, 2006).

In addition, military naval sector (ships construction and maintenance) is an important activity for the balance sheet of France's foreign trade.

In metropolitan France, the main naval bases are: Brest, Cherbourg and Toulon.

\subsection{Commercial harbours: goods, passengers}

Three quarters of world trade occurs by sea. Sea transport is in perpetual growth, especially since it remains the most economical (between 0.3 and $1.6 \%$ of the final price of the product) and ecological method of transport (CLUSTER MARITIME FRANCAIS, 2006). 
France is the $5^{\text {th }}$ commercial world power ( $5^{\text {th }}$ exporter and $6^{\text {th }}$ importer) based on the value of the goods. Two-fifth of the tonnage (40.6\%) and one fifth of the value (20.2\%) of France's foreign trade were transported through a seaport (DGMT, 2006). Classification of French ports among the European ports is presented in figure 1.

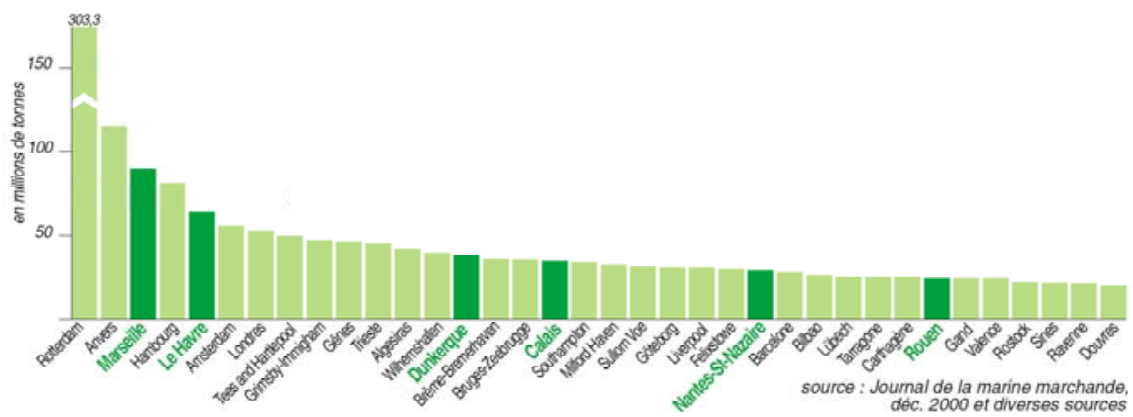

Figure 1. Classification of the main European ports according to their raw tonnage (millions tons) in 2000 (Atlas permanent de la Mer et du Littoral n5-Littoral français 2000, p38, CNRS et Géolittomer - LETG UMR 6554).

Ports and sea transport play an essential role for the imports of vital basic products for the economy (oil, ores, coal, fertilizers, foodstuffs), but also for the exchanges of manufactured goods with strong added value. In 2006, French seaports treated approximately 380 million tons of freight: half of which is liquid bulk (essentially oil), a quarter is dry bulk (cereal, coal, ores) and a quarter is containerised goods (DGMT, 2006).

A total amount of 564 ports with various activities (goods, passengers, fishing or sailing) are implanted along the French coasts. The main French commercial harbours (concerned by inquiry) are presented in figure 2.

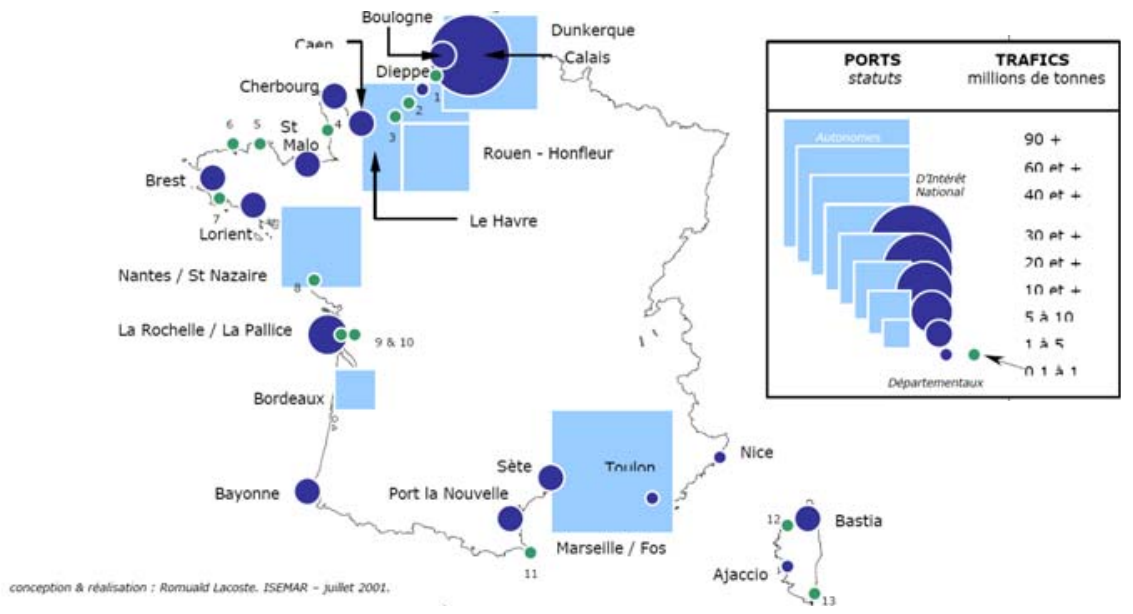

Figure 2. French ports traffic in 2000 (Trafic 2000 des ports maritimes métropolitains et des DOM - TOM, ISEMAR, July 2001). 
Autonomous Harbours treat more than $80 \%$ of sea traffic goods. National Interest Harbours treat the rest and more than $80 \%$ of the passenger's traffic.

Consequently, stakes associated with military and commercial harbours rest on a set of installations for which maintenance is necessary.

\section{Functional analysis}

The studied system includes all the installations which fulfil the harbours' functions relative to ships, or to the ground operations (primary activities). The part of the built assets which contributes to the development of secondary activities (industries, tourism, town planning and service, etc.) is also considered. All installations that are likely to interact with the primary and secondary activities are presented in figure 3 .

The role of the system can be assured only if all the functional domains are successful. In example, for a commercial harbour:

a) The ship must be able to fasten quickly and easily to its berthing and mooring structure. For this reason, the ship is sometimes obliged to cross diverse docks, sluice and locks before arriving alongside the quay.

b) The goods must be able to be quickly transhipped or, if necessary, stored for a more or less long time in the port with the aim of its forwarding, all of this with the lowest cost.

c) Finally, goods either go into an industrial transformation process inside the ports boundaries, or have to pass in transit through the port to connections with the outside transport networks by ground transportation (roads, railroads) andlor ways of inner navigation.

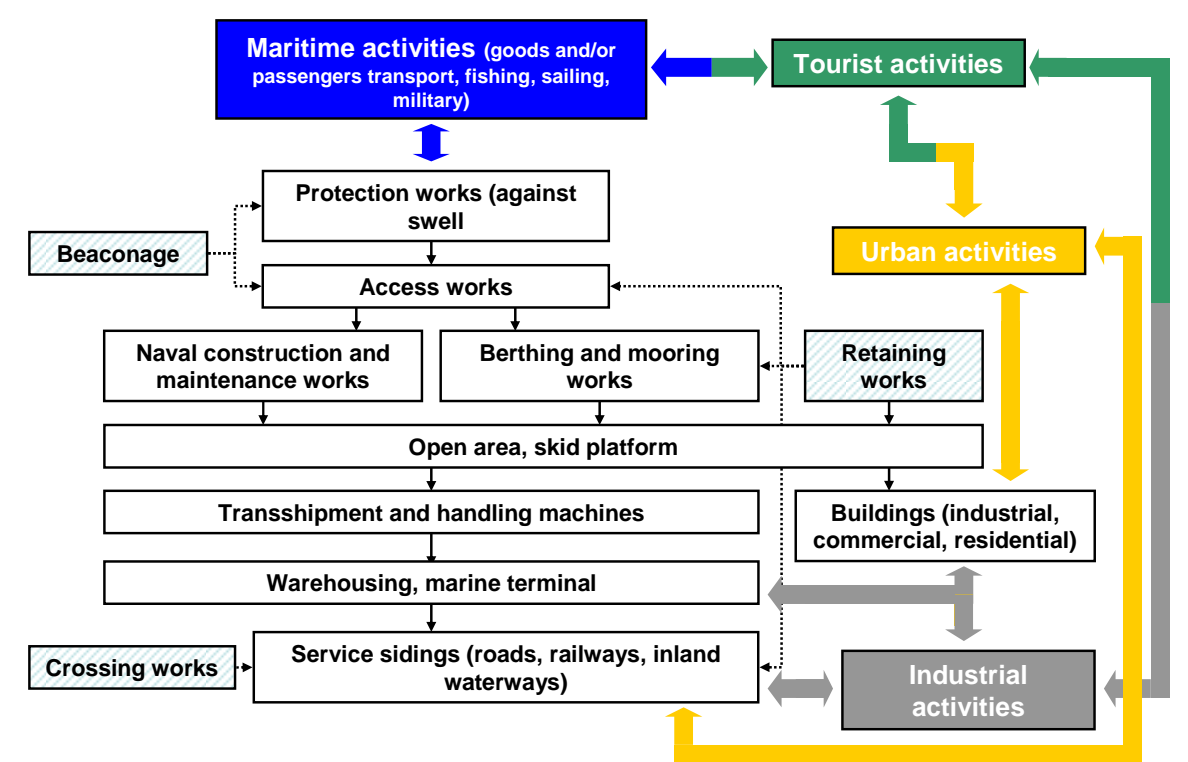

Figure 3. Activities in interaction with the structures composing the harbour system. 


\section{Quantitative patrimonial analysis}

In this paper, we focus on the berthing and mooring works. Cranes, pavements, warehouses and sheds are not included in our analysis. Note that built assets belong mainly to public authorities and only some wharves are owned by private companies. In this analysis, only the length of the structures is considered as an indicator for the ranking of built assets. This allows for the comparison of berthing and mooring works realized with various construction techniques. Note that the "height $\times$ length" area is more adapted than the length, but this information was not available at the time of the inquiry.

\subsection{Typological analysis}

This information was not available from military harbours, and therefore this analysis only considers $\mathrm{AH}$ and NIH. The distribution, in linear kilometres, of the construction techniques used for the berthing and mooring's structures is presented in figure 4.

They are classified from right to left in order of chronological appearance but, after the six first ones, techniques coexist.

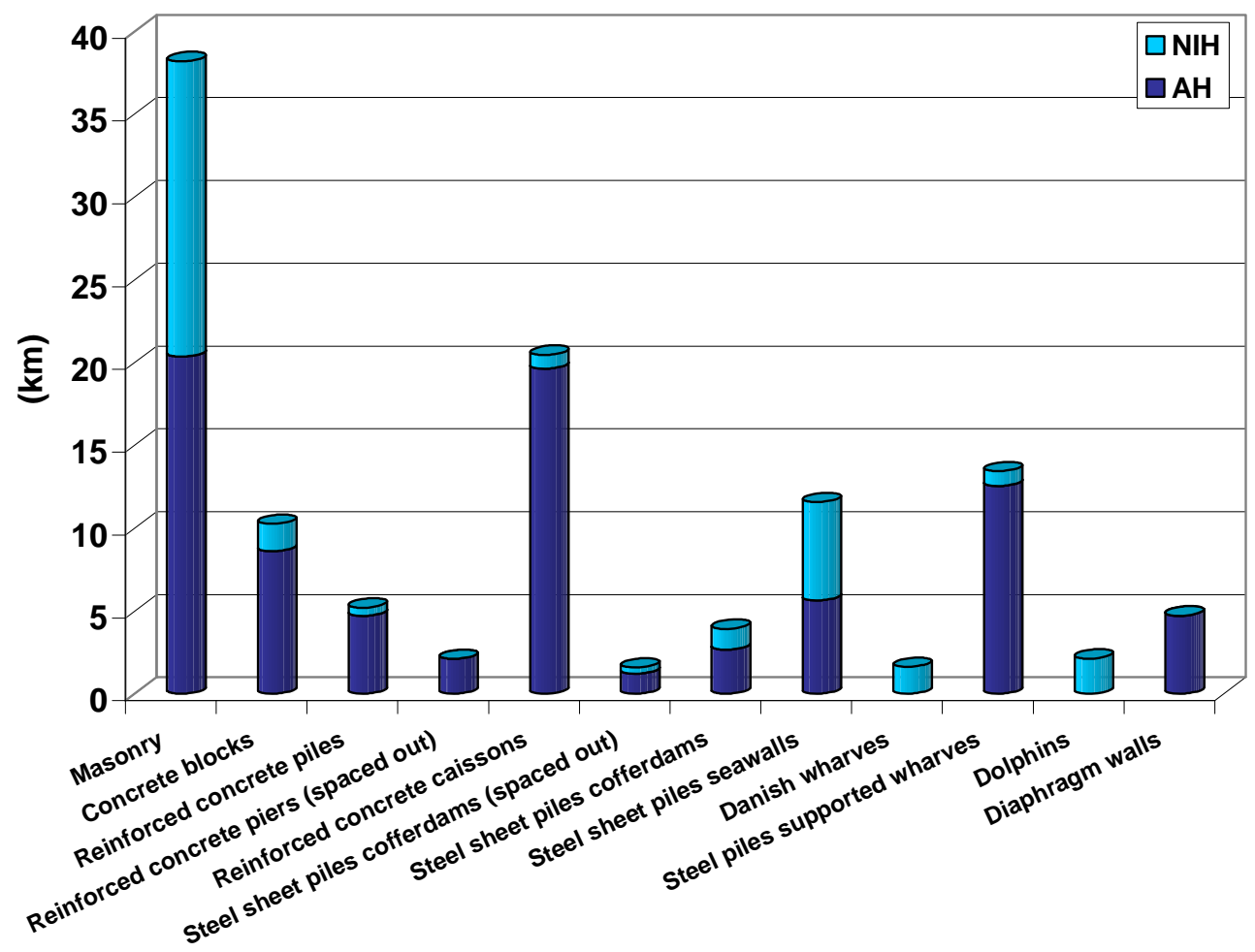

Figure 4. Distribution of construction techniques of berthing and mooring structures.

The great majority of the structures are masonry, followed by concrete blocks, reinforced-concrete caissons, steel piles supported wharves, steel sheet piles seawalls and diaphragm walls. This figure illustrates the inventiveness of engineers confronted 
with the challenges of designing maritime structures; however it also means that owners are faced with delicate management decisions with regards to the principles of mechanical functioning and multiple failure modes.

A part of the answer is in the monitoring (survey) of structures and the instrumentation of the more recent ones (DELATTRE \& MESPOULHE, 1999; GATTERMANN et al., 2001; SCHOEFS et al., 2004; YANEZ-GODOY \& SCHOEFS, 2006; YANEZGODOY et al., 2008), especially to re-evaluate their reliability (YANEZ-GODOY et al., 2006). This double level of heterogeneity (concept and material) is one of the issues that the GEROM project wishes to address.

\subsection{Age analysis}

The distribution of harbour infrastructure ages is presented in figure 5 for the three types of owners. Even if the main part of the structures was built more than 25 years ago, the owners don't have equivalent built assets:

a) NIH manage built assets for the main part dating before the twentieth century (essentially in masonry).

b) $\mathrm{MH}$ have built assets essentially bound to the reconstruction period after the Second World War, and thus previous to 1955.

c) AH have more recent built assets that appeared mainly between 1955 and 1980 .

This can be explained by a more recent status and a growth strongly linked to economic development.

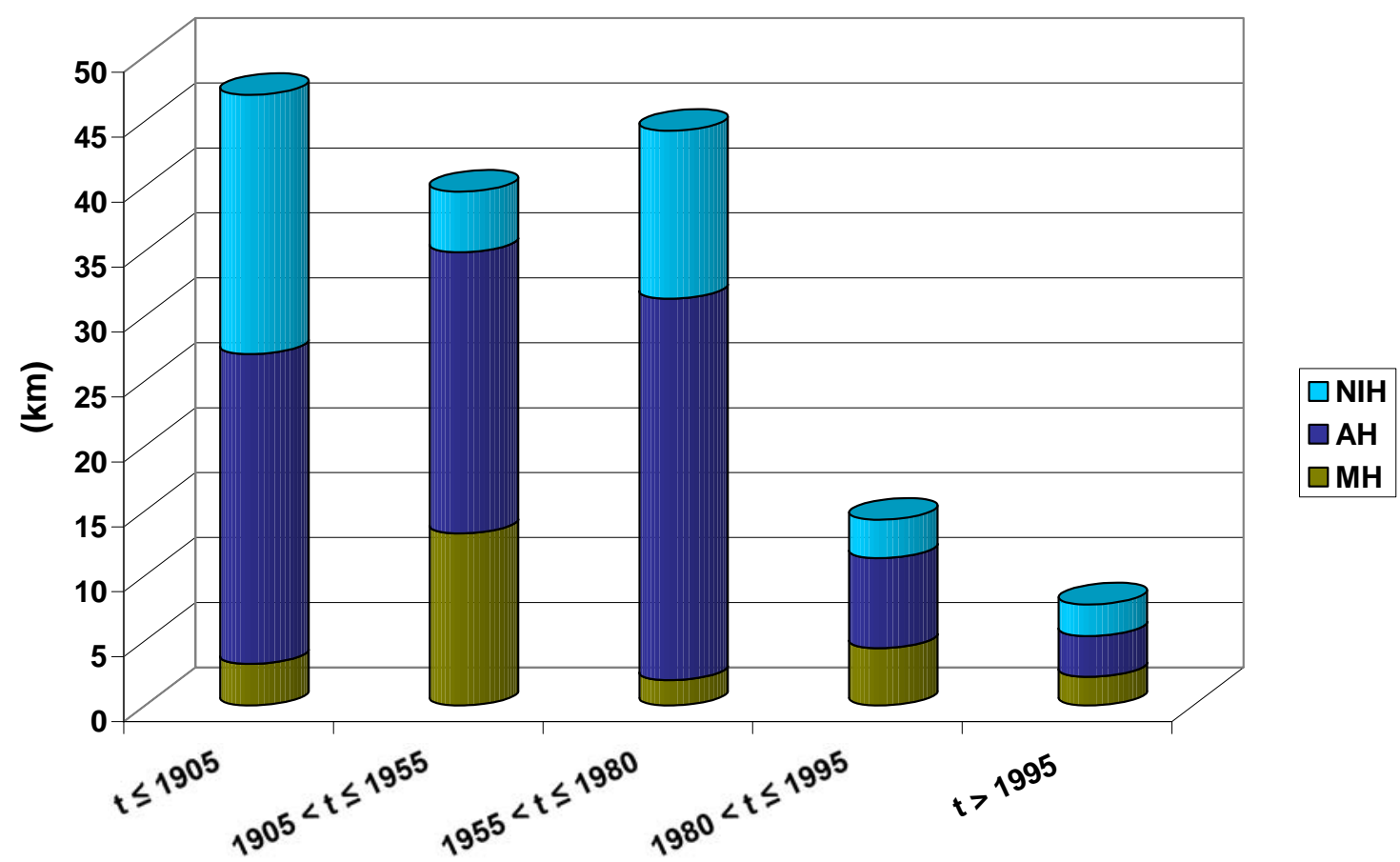

Figure 5. Age distribution of berthing and mooring structures. 
These results can be further analyzed by studying the amount of investment in nonmilitary harbour facilities published in March 1994 by the Economic Observatory of Transport Statistics. Even if investments concern all harbour infrastructures, the trend is the same: in constant francs (year for reference: 1980), approximately 1400 million francs (213 million euros) were invested from 1957 to 1970, then investments increase strongly until 1975 with 2500 million francs (381 million euros) in average, exceeding even 3000 million francs (457 million euros) in 1975 and levelling out at the end of the 80s at a value of 700 million francs (107 million euros).

\subsection{Economic analysis}

Roughly $205 \mathrm{~km}$ of berthing and mooring structures were analyzed during the inquiry; $64 \%$ (130 km) are managed by AH, 24\% (50 km) by NIH and 12\% (25 km) by MH.

To compare the economic role of these structures, we consider the weight of goods as published by DGMT (2006). Through the ratio of million tons of raw goods by linear kilometre (Mt / km), the inquiry supplied interesting data: a third of NIH treats a very weak tonnage under $100 \mathrm{t} / \mathrm{km}$, another third, a ratio of the order of $0.5 \mathrm{Mt} / \mathrm{km}$, and the rest a $1 \mathrm{Mt} / \mathrm{km}$ ratio; $\mathrm{AH}$ have a ratio exceeding $2 \mathrm{Mt} / \mathrm{km}$ with $3 \mathrm{Mt} / \mathrm{km}$ in average.

One National Interest Harbour has a very particular profile due to the Trans-Channel traffic fluidity and dynamism and reaches $6 \mathrm{Mt} / \mathrm{km}$. The economic analysis needs specific studies in every harbour and it is not discussed here.

This information could be completed by a more specific analysis that considers the value and nature of goods for instance. However, as this information is highly likely to vary, the authors prefer not to conduct further investigation along these lines.

\section{Conclusions}

This article presents the first part of the results of the national inquiry of the technical management of maritime harbour structures undertaken in 2006-2007. Results show a significant heterogeneity between the structures in age and in construction technique.

The great majority of the structures are in masonry which corresponds to the oldest part of the built assets. After the Second World War, other construction techniques were used due to the characteristics of ships, site conditions and economic factors. Consequently the built assets are varied.

To perform a more detailed analysis, indicators other than length can be quantified in order to specify the maintenance requirements. For instance, the surface in square kilometres could be selected in future works as a more accurate factor to quantify maintenance stakes. 


\section{Acknowledgements}

This study is led within GEROM (contact: franck.schoefs@univ-nantes.fr), project financed by the company OXAND and led within the Grouping of Scientific Interest MRGenCi. The authors thank the CETE de l'Ouest for its contribution to the inquiry phase and all the owners who were kind enough to grant time to this project.

\section{References}

AIPCN (2001). Life cycle management of port structures - general principles. Marcom report of Working Group 31.

AIPCN (2008). Implementation manual for life cycle management of port structures. Marcom report of Working Group 42.

BILLARD Y., BERNARD O., LASNE M., SCHOEFS F. (2006). Risk analysis for survey optimisation of harbours. Proc. of the Third ASRANet colloquium 2006, Glasgow, UK, July 10-12, 2006, paper 028-109 on CD, 9 pages.

BILLARD Y., BERNARD O., LASNE M., CAPRA B., SCHOEFS F., BOERO J. (2007). Risk analysis and reliability of repaired concrete quays. Proceeding of 10th I.C.A.S.P conference, July 31-August 3 2007, Kashiwa Campus, The University of Tokyo, Tokyo, Japan, 8 pages.

BOERO J., CAPRA B., SCHOEFS F., BERNARD O., LASNE M. (2006). Analyse de risques pour la maintenance des structures portuaires : exemple de quais gabions soumis à de la corrosion. IXèmes Journées Génie Civil - Génie Côtier, Brest, 12-14 septembre 2006, pp 585-592. [URL http://www.paralia.fr/Files/09_56_8p_boero.pdf ] CLUSTER MARITIME FRANÇAIS (2006). Le Cluster Maritime Français, Poids économique et social de la France maritime. Brochure, 2006-2007.

CNRS (2000). Atlas permanent de la Mer et du Littoral n5-Littoral français 2000. P38, CNRS - Géolittomer - LETG UMR 6554.

DELATTRE L., MESPOULHE L. (1999). Etude expérimentale du comportement du quai en eau profonde du port de Calais. Rapport, no. 65. Paris, France: Laboratoire Central des Ponts et Chaussées, 193 p.

DGMT -Direction Générale de la Mer et des Transports- (2006). Ports maritimes, flottes de commerce, voies navigables. Résultats 2005 provisoires.

GATTERMANN J., BERGS T., RODATZ W. (2001). Modified instrumentation and results of stress and deformation monitoring at the new quay wall construction Container Terminal Altenwerder, Port of Hamburg. Proceedings of the 8th International Conference on Structural Safety and Reliability (ICOSSAR'01), 17-22, June, 2001, Newport Beach, CA, USA.

HALDI A. (1997). Risque et sécurité des systèmes techniques. Cours Postgrade, Module G2: Analyse de risques, Département de Génie Civil, Laboratoire de Systèmes Energétiques (LASEN), EPFL. 
ISEMAR -Institut Supérieur d'Economie Maritime- (2001). Trafic 2000 des ports maritimes métropolitains et des DOM - TOM.

MARINE NATIONALE. (2006). Dossier d'Information Marine. Publication du ministère de la défense. Bureau EMM/PILOTAGE, emm.pilotage@marine.defense.gouv.fr.

PEYRAS L., ROYET P., SALMI A., SALEMBIER, BOISSIER D. (2006). Étude de la sûreté de fonctionnement d'un aménagement hydraulique de génie civil. Application à des ouvrages de protection contre les inondations de la ville de Nîmes. Fiabilité des matériaux et des structures, analyse de risques, REGC civil Vol. 10, n 5, pp 615-631.

SCHOEFS F., GERARD B., CASARI P., VERDURE L. (2004). Stratégie d'instrumentation pour la gestion optimisée des ouvrages portuaires. VIIIèmes Journées Nationales Génie Côtier-Génie Civil, Compiègne, France, 7-9 septembre 2004, pp 513520. [URL http://www.paralia.fr/Files/08_57_8p__schoefs.pdf ]

SORENSEN J.D., BURCHARTH H.F. (2004). Risk-based optimization and reliability levels of coastal structures. International Forum on Engineering Decision Making, First Forum December 5-9, 2004, Stoos, Switzerland.

VILLEMEUR A. (1988). Sûreté de fonctionnement des systèmes industriels. Fiabilité, facteurs humains, informatisation. Collection de la direction des études et recherches d'Electricité de France.

YAÑEZ-GODOY H., SCHOEFS F. (2006). Analyse comparée du chargement horizontal de deux quais sur pieux en service à partir d'instrumentations. IXèmes Journées Nationales Génie Côtier - Génie Civil, Brest, 12-14 septembre 2006, pp 653662. [URL http://www.paralia.fr/Files/09_63_10p_yanes_godoy.pdf ]

YAÑEZ-GODOY H., SCHOEFS F., NOUY A., CASARI P. (2006). Extreme storm loading on in-service wharf structures : interest of monitoring for reliability updating, numéro spécial "Fiabilité des matériaux et des structures et analyse des risques". Revue Européenne de Génie Civil, Volume 10, n 5, Hermès / Lavoisier, pp. 565-581. YAÑEZ-GODOY H., SCHOEFS F., CASARI P. (2008). Statistical Analysis of the Effects of Building Conditions on the Initial Loadings of On-piles Quays. Structural Health Monitoring (SAGE), Vol. 7, pp 245-263. 
6.12 : Revue Paralia - n² (2009) 